\title{
Stem Water Potential and Apple Size
}

\author{
Amos Naor \\ Golan Research Institute, P. O. Box 97, Kazrin 12900, Israel \\ Isaac Klein \\ Institute of Horticulture, ARO, The Volcani Center, Bet Dagan 50250, Israel
}

Israel Doron

Extension service, Ministry of Agriculture, P. O. Box 50, Kazrin 12900, Israel

Additional index words. Malus domestics, irrigation, leaf water potential, stem water potential, water stress

\begin{abstract}
The sensitivity of leaf $\left(\psi_{\text {leaf }}\right)$ and stem $\left(\psi_{\text {stem }}\right)$ water potential and stomatal conductance ( $\left.g_{\mathrm{s}}\right)$ to soil moisture availability in apple (Malus domestics Borkh.) trees and their correlation with yield components were studied in a field experiment. Two drip irrigation treatments, $440 \mathrm{~mm}(\mathrm{H})$ and $210 \mathrm{~mm}(\mathrm{~L})$, were applied to a 'Golden Delicious' apple orchard during cell enlargement stage (55-173 days after full bloom). Data collected included $\psi_{\text {stem }}, \mathbf{y}_{\text {leaf, }} \mathbf{g}_{s}$, and soil water potential at $25\left(\psi_{\text {soil-25 }}\right)$ and $50 \mathrm{~cm}\left(\psi_{\text {soil.50 }}\right)$. No differences in midday $\psi_{\text {leaf }}$ 's were found between irrigation treatments. Stem water potential was higher in the $H$ treatment than in the $L$ treatment in diurnal measurements, and at midday throughout the season. Stomatal conductance of the $H$ treatment was higher than the $L$ treatment throughout the day. Stomatal conductance between 0930 and $1530 \mathrm{HR}$ were highly correlated with $\psi_{\text {stem }}$. The $\mathbf{H}$ treatment increased the percentage of fruit $>65 \mathrm{~mm}$, and increased the proportion of earlier harvested fruit reaching marketable size compared to the $L$ treatment. Fruit size in the first harvest and the total yield were highly correlated with $\psi_{\text {stem }}$. The degree of correlation between plant water stress indicators and yield component decreased in the following order: $\psi_{\text {stem }}>\psi_{\text {soil-25 }},>\psi_{\text {soil-50 } 5}>\psi_{\text {lear }}{ }^{\circ}$ The data suggest that midday $\psi_{\text {stem }}$ may serve as a preferable plant water stress indicator with respect to fruit size.
\end{abstract}

Measurements of soil water status have been widely used for irrigation scheduling in orchards (Campbell and Campbell, 1982; Levin et al., 1979). However, determination of soil water availability requires numerous discrete spatial measurements and integration of results for estimation of available soil water around a single emitter. The number of required measurements is particularly large under drip irrigation, where three dimensional gradients of water exists in the soil. Furthermore, measurements around many emitters are needed to average soil water content in commercial orchards because of spatial variability of soil hydraulic parameters (Warrick and Nielsen, 1980).

Plant water status is a function of soil water availability, hydraulic resistance along the flow path, plant water capacitance, and meteorological conditions that determine atmospheric evaporative demand. Commonly, soil water is allowed to be depleted to a certain level before irrigation. The extent of the allowed depletion, before damage occurs, has to be determined experimentally. Rapid changes in climatic conditions may cause abrupt changes in plant water status. The required threshold level of available water under variable climatic conditions may change because of the nonsteady water flow type in the soil-plant-atmosphere continuum. The difficulties encountered in determining soil water availability make it desirable to use plant water status indicators as an additional tool for irrigation scheduling.

Several physiological indicators, i.e., trunk and fruit diameter changes (Kalmar and Lahav, 1977; Tromp 1984), and fruit growth rate (Assaf et al., 1982; Forshey and Dominick 1965; Furr and Taylor, 1939; Goel and Cohen, 1989) were proposed as measures for irrigation scheduling. Predawn leaf water potential has been found to be in correlation with soil water content since it closely

Received for publication 13 June 1994. Accepted for publication 7 Feb. 1995. The fruitful discussions with Ed Proebsting on water relations in apple trees are gratefully acknowledged. The cost of publishing this paper was defrayed in part by the payment of page charges. Under postal regulations, this paper therefore must be hereby marked advertisement solely to indicate this fact. represents soil water availability after equilibration of soil-plant potentials at the end of the night (Xiloyanis, 1980). Midday leaf water potential was found to be a sensitive measure of plant water status in apple (Erf and Proctor, 1987) and grapevines (Naor et al., 1993) and insensitive in many other cases, i.e., peach (Gamier and Berger, 1985), prune (McCutchan and Schackel, 1992), and grapevine (Naor and Wample, 1994). Midday stem water potential, in contrast to midday leaf water potential, was found to be a sensitive measure of plant water status throughout the entire day (Gamier and Berger, 1985; McCutchan and Shackel, 1992; Naor and Wample, 1994).

The objectives of the present investigation were to study the response of leaf and stem water potentials to soil water availability in apple trees and their correlation with yield components.

\section{Materials and Methods}

Experimental site. An irrigation experiment was conducted in a 6-year-old commercial apple orchard of 'Golden Delicious' grafted on 13/4 'Hashabi' rootstock in the Golan Heights, Israel, on a shallow basaltic soil $50 \mathrm{~cm}$ deep. The trees were spaced $4 \times 2.5$ $\mathrm{m}$ apart and irrigated by two laterals of in-line 2.3-liter $\mathrm{h}^{-1}$ drippers, spaced at $80 \mathrm{~cm}$ intervals along laterals. The experimental site was located $33^{\circ} \mathrm{N}, 36^{\circ} \mathrm{E}$, in a semiarid zone with no summer rains, 950 $\mathrm{m}$ above sea level. Average winter precipitation (October-April) in the area is about $1000 \mathrm{~mm}$.

Experimental plots. Two irrigation treatments were replicated five times using a randomized block design along four adjacent rows. The outer two rows were planted with 'Starking Delicious' as pollenizer. Each replicate consisted of 16 trees. Measurements were taken from the center four trees of each replicate. A uniform irrigation regime was applied for both treatments from 1 May 1993 (fruit set) until 19 June 1993 (day $170=55$ days after full bloom), the end of vigorous shoot growth and fruit cell division stage (Bollard, 1970). A total of $80 \mathrm{~mm}$ of irrigation was applied during this period, which was the commercial practice in the region. 


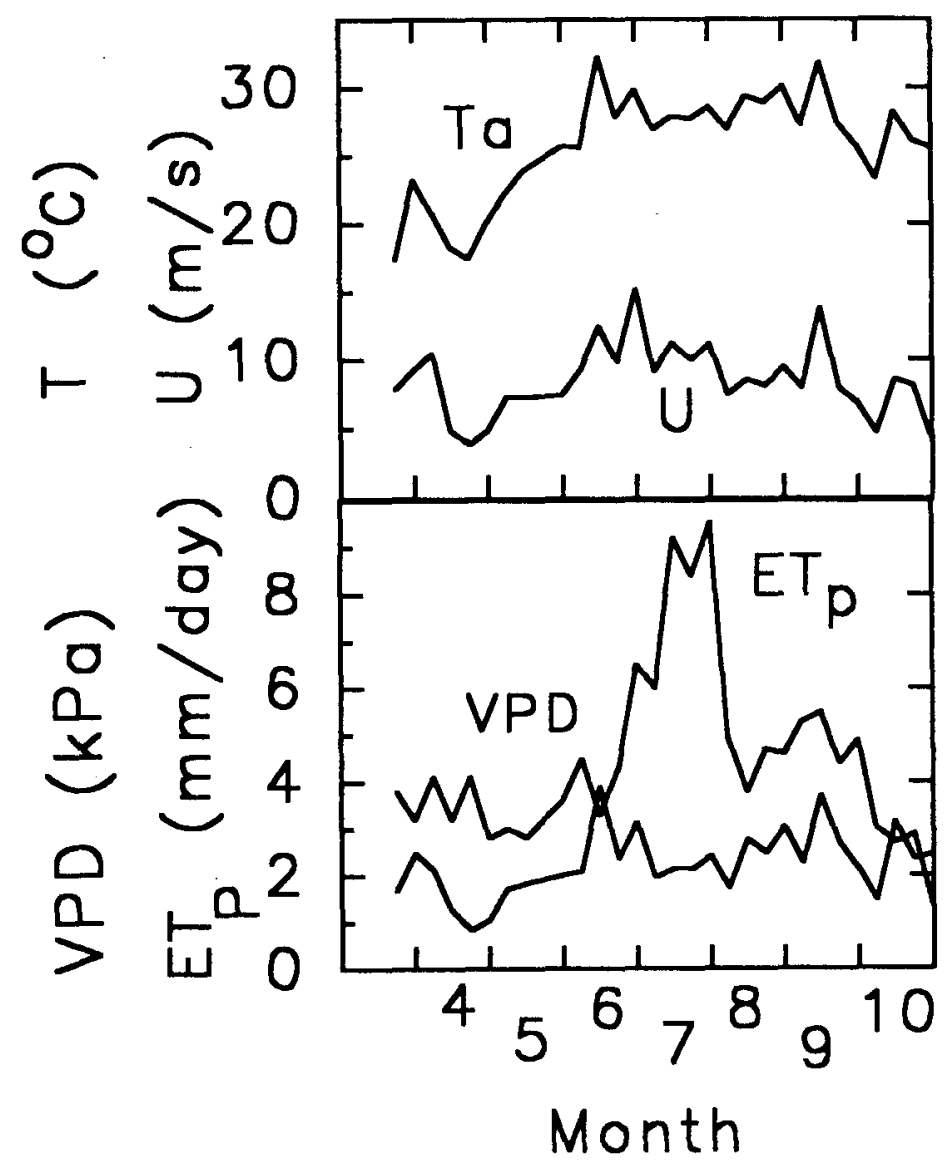

Fig. 1. Maximum air temperature (Ta), mean wind speed at $2 \mathrm{~m}$ height (U), vapor pressure deficit (VPD), and potential evapotranspiration for grass (ETp) during 1993, measured $1.5 \mathrm{~km}$ from the experimental site.

Irrigation treatments. Two drip irrigation treatments, $440 \mathrm{~mm}$ $(\mathrm{H})$ and $210 \mathrm{~mm}(\mathrm{~L})$, were applied during cell enlargement stage (55-173 days after full bloom). The orchard was irrigated at 3- to 4-day intervals until the start of the experiment and at 2-day intervals thereafter to reduce water percolation below the root zone.

Measurements. Meteorological data were measured in a standard electronic weather station located $1.5 \mathrm{~km}$ from the orchard. Parameters measured included air temperature, air humidity, wind speed $2 \mathrm{~m}$ above ground and photosynthetically active radiation (PAR). Daily values of maximum temperature, maximum vapor pressure deficit, average wind speed, and daily potential grass evapotranspiration (calculated using the Penman equation) were recorded (Fig. 1). A class A evaporation pan was located at the experimental site.

Ten tensiometer stations per treatment (two stations per replicate) were installed $25 \mathrm{~cm}$ from the drippers. Each station consisted of two tensiometers. inserted at depths of 25 and $50 \mathrm{~cm}$. Soil water potential was measured 2-3 times a week, before $0800 \mathrm{HR}$. Because of the large variability in tensiometers readings, data from both readings per plot were excluded when differences between the two readings exceeded $25 \mathrm{kPa}$. Otherwise, readings at each plot were averaged.

Leaf water potential was measured on fully expanded leaves facing the sun. The leaves were detached, placed immediately in a plastic bag and leaf water potential determined in a pressure chamber (Ari-mad, Kfar Charuv, Golan Heights, Israel). To measure stem water potential, two intact leaves per replicate were selected from the inner part of the canopy. The leaves were enclosed, while intact on the tree, in a plastic bag covered with aluminum foil and left $90 \mathrm{~min}$ for stem and leaf water potential to equilibrate before measurement. Two pressure chambers were used simultaneously to complete each set of measurements rapidly to minimize the time elapsed between the first and the last measurement of each set. The average of two leaves was taken to represent each replicate. Midday measurements of leaf and stem water potentials were taken during several days in mid-summer. Diurnal measurements of leaf and stem water potential were taken on 4 Aug. 1993. Diurnal measurements started at $0700 \mathrm{HR}$ and ended at $1800 \mathrm{HR}$. Before each measurement of leaf water potential, stomatal conductance was measured using a portable photosynthesis system (LCA2, ADC, U.K.). The same leaves were used for stomatal conductance and leaf water potential measurements.

Total light interception, for evaluation of canopy coverage, was measured "on 4 Aug. 1993, when annual shoot and leaf development was complete. Light intensity reaching the soil surface was measured with an 80-cm, 80-sensors line PAR Ceptometer (Delta

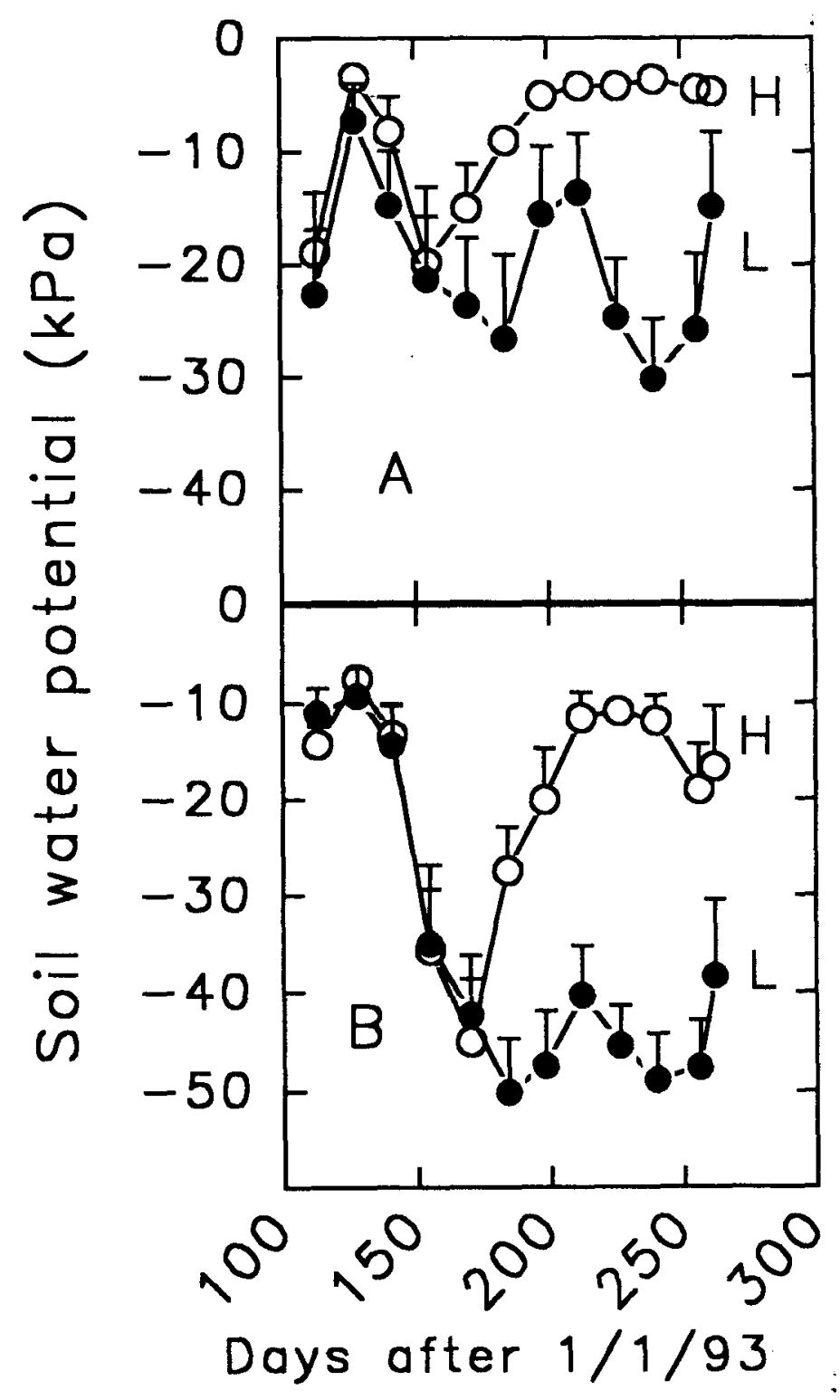

Fig. 2. Soil water potential in the low (closed circles) and high (open circles) irrigation rate treatments at (a) $25 \mathrm{~cm}$ and (b) $50 \mathrm{~cm}$ depth. Bars denote standard error when larger than symbol size. 
T Devices Ltd, Burwell, Cambridge, U. K.) on the area between the trunks of the four measured trees of each replicate. Measurements were taken along five transects between rows and five perpendicular transects, covering the area between four trunks in a $50-\mathrm{cm}$ grid. Measurements were taken from dawn to dark in about 90-min intervals. At each measurement time the percentage of area covered by canopy was calculated as $100 \mathbf{x}(\mathbf{1}$ - light intensity below canopy/light intensity above canopy). Measurements were integrated along the day to give percentage of canopy coverage.

Fruit was picked selectively in two harvests. The first harvest, of fruit having diameter $>60 \mathrm{~mm}$, was on $15 \mathrm{Sept}$. 1993. The remaining fruit, left to reach their maximum potential size, were picked on 15 Oct. 1993. Fruit size distribution was determined for each harvest.

Statistical analysis. Statistical analyses of variance were performed, including Duncan's multiple range test using GLM procedure (SAS, Cary, N.C.). Correlations between measured parameters were calculated using CORR procedure (SAS)

\section{Results and Discussion}

Monthly average of daily pan evaporation rates were 8.2,9.0, 8.0, and $6.5 \mathrm{~mm}$ during June, July, August, and September, respectively. Cumulative (19 June-15 Oct.) pan evaporation was $1100 \mathrm{~mm}$ and irrigation was 440 and $210 \mathrm{~mm}$ in the $\mathrm{H}$ and the $\mathrm{L}$ treatments, respectively. These values correspond to pan evapora-

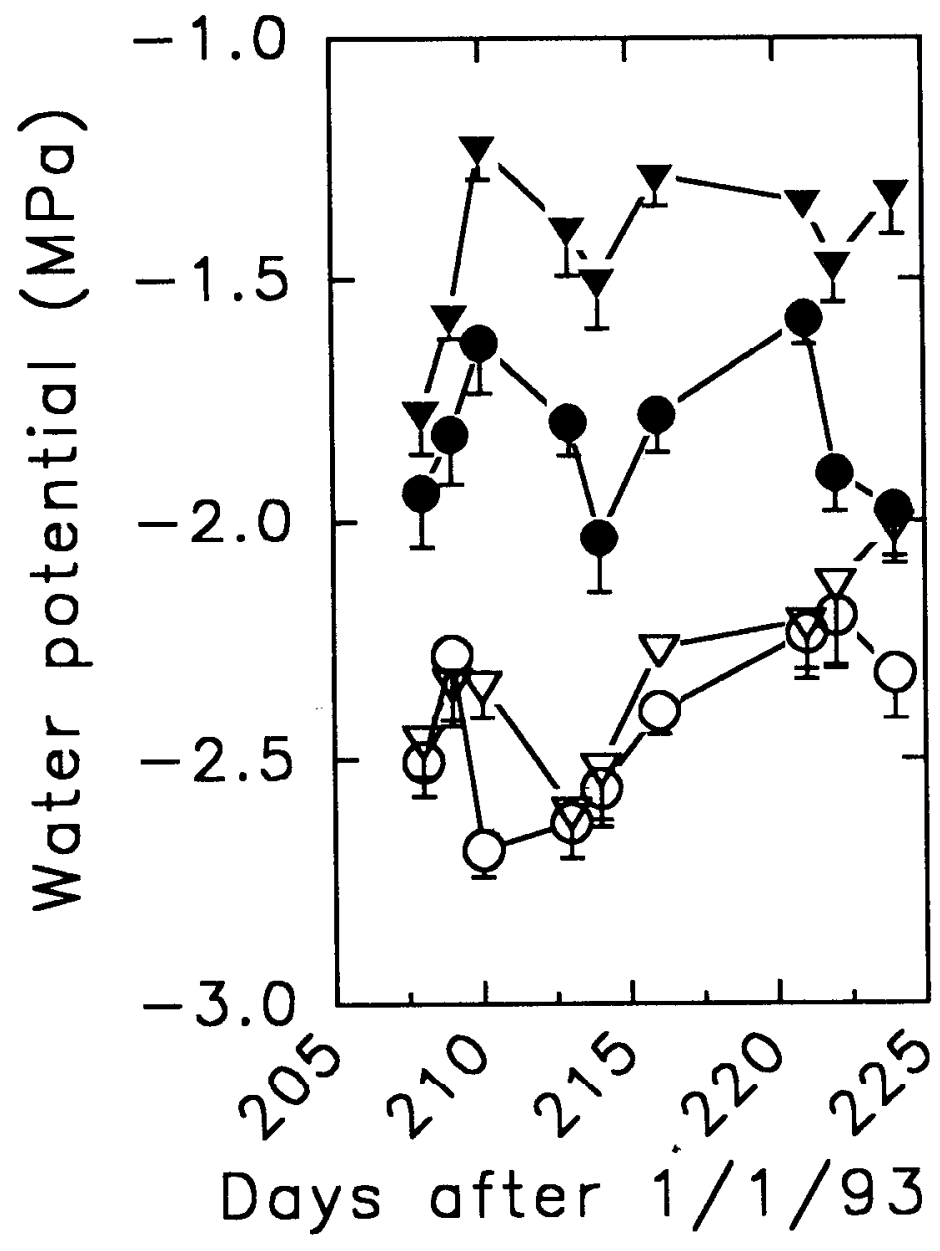

Fig. 3. Midday leaf (open symbols) and stem (closed symbols) water potentials in 'Golden Delicious' apple irrigated with low (circles) and high (triangles) rates of water during the cell enlargement phase. Bars denote standard error when larger than symbol size.

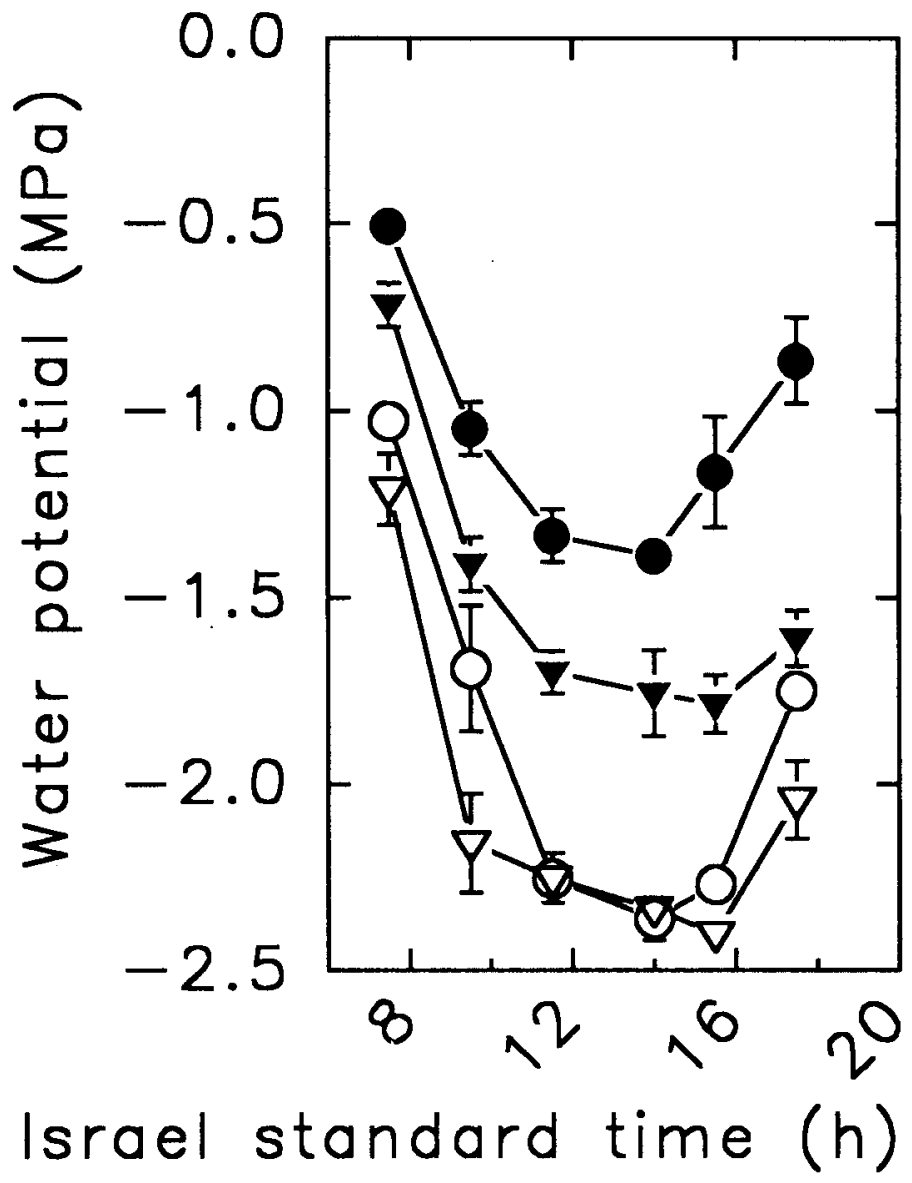

Fig. 4. Diurnal measurements on 4 Aug. 1993 of leaf (open symbols) and stem (closed symbols) water potential of 'Golden Delicious' apple trees irrigated with low (triangles) and high (circles) rates of water. Bars denote standard error when larger than symbol size.

tion coefficients of 0.40 and 0.19 in the $\mathrm{H}$ and $\mathrm{L}$ treatments respectively. Average canopy coverage was $54 \%$, which is considerably less than about $80 \%$ in mature orchards. Taking into account the experimental trees canopy size, the irrigation coefficients equivalent to full canopy coverage were 0.59 and 0.28 in the Hand L treatments, respectively.

Similar soil water potentials were measured in the two irrigation treatments during the cell division phase, at the $25\left(\psi_{\text {soil-25 }}\right)$ and $50 \mathrm{~cm}\left(\psi_{\text {soil-50 }}\right)$ depths (Fig. 2). Differences in $\psi_{\text {soil }}$ between treatments increased gradually after differential irrigation started at day 170 (55 days after full bloom). Average $\psi_{\text {soil }}$ in the $\mathrm{H}$ and $\mathrm{L}$ treatments during the cell enlargement phase (after day 200) were -5 and $-25 \mathrm{kPa}$ at $25 \mathrm{~cm}$ depth, and -7 and $-40 \mathrm{kPa}$ at $50 \mathrm{~cm}$ depth, respectively. Differences between treatments were greater at 50 $\mathrm{cm}$ depth compared to $25 \mathrm{~cm}$ depth.

With two exceptions, similar midday leaf water potentials $\left(\psi_{\text {leaf }}\right)$ were found in both treatments on days 208-225 of the measured period (Fig. 3). In contrast, midday stem water potential $\left(\psi_{\text {stem }}\right)$ of the $\mathrm{H}$ treatment were higher than the $\mathrm{L}$ treatment at all dates measured. These findings are in agreement with other reports on peach (Gamier and Berger, 1985), prune (McCutchan and Shackel, 1992), and grapevine (Naor and Wample, 1994), which indicate that midday y stem is a better predictor of plant water status. Based on midday measurements, it may be concluded that irrigation levels did not affect $\psi_{\text {leaf }}$. However, diurnal $\psi_{\text {leaf }}$ measurements showed that, during morning and late afternoon, differences in $\psi_{\text {leat }}$ were found between treatments (Fig. 4).

Stomatal conductance $\left(\mathrm{g}_{\mathrm{s}}\right)$ of the $\mathrm{H}$ treatment was higher than 
that of the L treatment throughout the entire day (Fig. 5). The $\mathrm{g}_{\mathrm{s}}$ of both treatments peaked at $0900 \mathrm{HR}$ and then decreased. The decline of $g_{s}$ in the $\mathrm{H}$ treatment may indicate that some stress existed even in the higher rate of irrigation.

Stomatal conductance was highly correlated $\left(r^{2}=0.90\right.$, significant at $P=0.001$ ) with $\psi_{\text {stem }}$ measured at $0930-1530 \mathrm{HR}$ (Fig. 6). The leaves during early morning measurements were shaded by the adjacent row because of low sun angle. The light saturation threshold for stomatal aperture in apples is $600 \mu \mathrm{mol} \cdot \mathrm{m}^{-2} \cdot \mathrm{s}^{-1}$ (Jones, 1992). It seems, therefore, that lower morning $\mathrm{g}_{\mathrm{s}}$ is indicative of light limitation of stomatal aperture. Late afternoon $g_{s}$ were low in both treatments. This might be explained in part by reduced light intensity. An additional explanation is that the recovery of $\mathrm{g}_{\mathrm{s}}$ from water stress lags after increase in water potential (Boyer, 1971). When $g_{s}$ of apple rootstock was presented as a function of $\psi_{\text {stem }}$ (data from Olien and Lakso, 1986), the same hysteresis was observed. Therefore, for nonlimiting light conditions and over the time period when water stress is increasing, $\mathrm{g}_{\mathrm{s}}$ is highly correlated with $\psi_{\text {stem }}$. Ebel (199 1) reported a nonlinear relationship between $\psi_{\text {stem }}$ and $g_{s}$ when $\psi_{\text {stem }}$ ranged from -0.5 MPa to 3.5 MPa. A linear relationship would fit to Ebel (1991) data in $\psi_{\text {stem }}$ range similar to that of our study.

Total yield in the first harvest in the $\mathrm{H}$ treatment was higher than in $\mathrm{L}$ treatment (Table 1) where crop levels were similar. Differential irrigation treatments were initiated after cell number per fruit was already established (Bollard, 1970). Therefore, the higher yield in the first harvest in $\mathrm{H}$ treatment can be attributed solely to

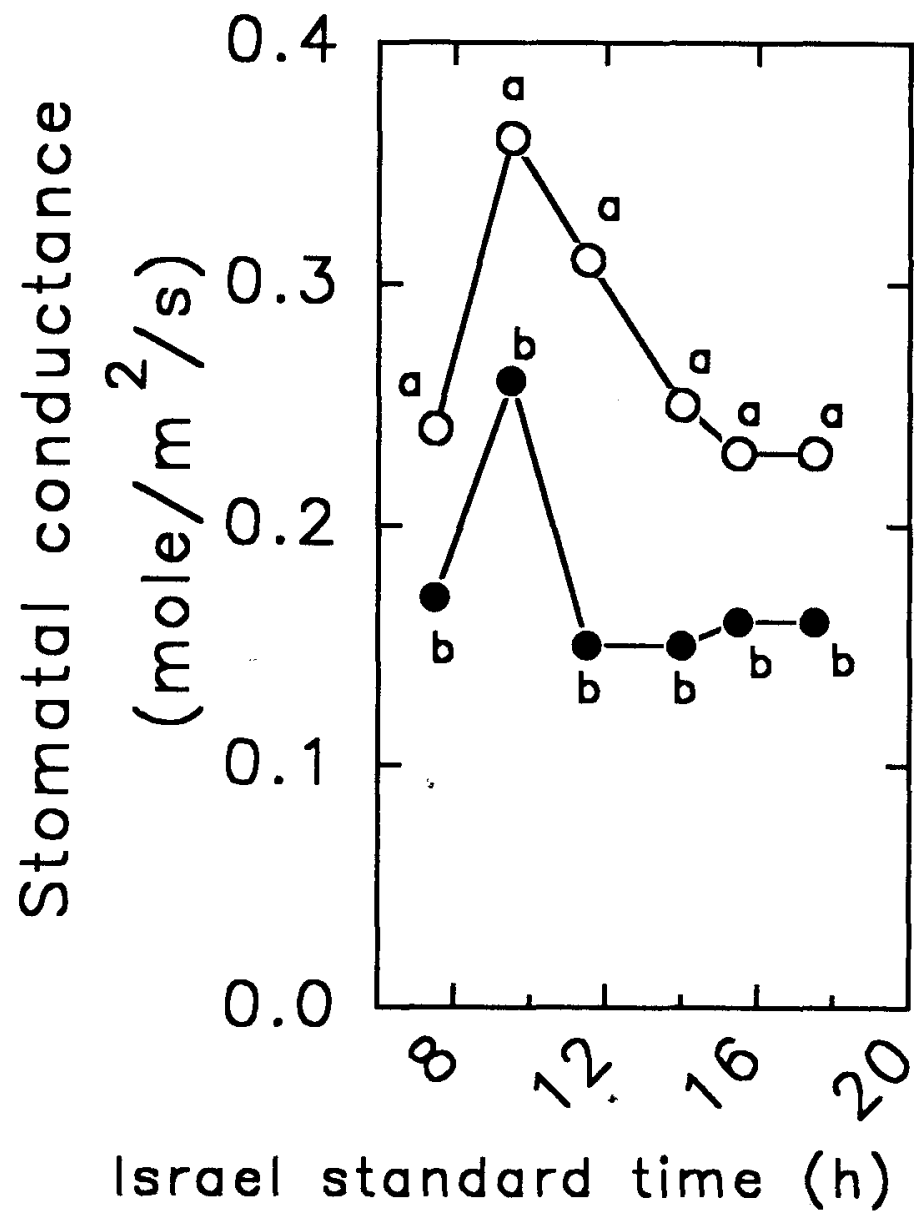

Fig. 5. Diurnal measurements on 4 Aug. 1993 of Stomatal conductance in 'Golden Delicious' apple trees irrigated with low (closed circles) and high (open circles) rates of water.

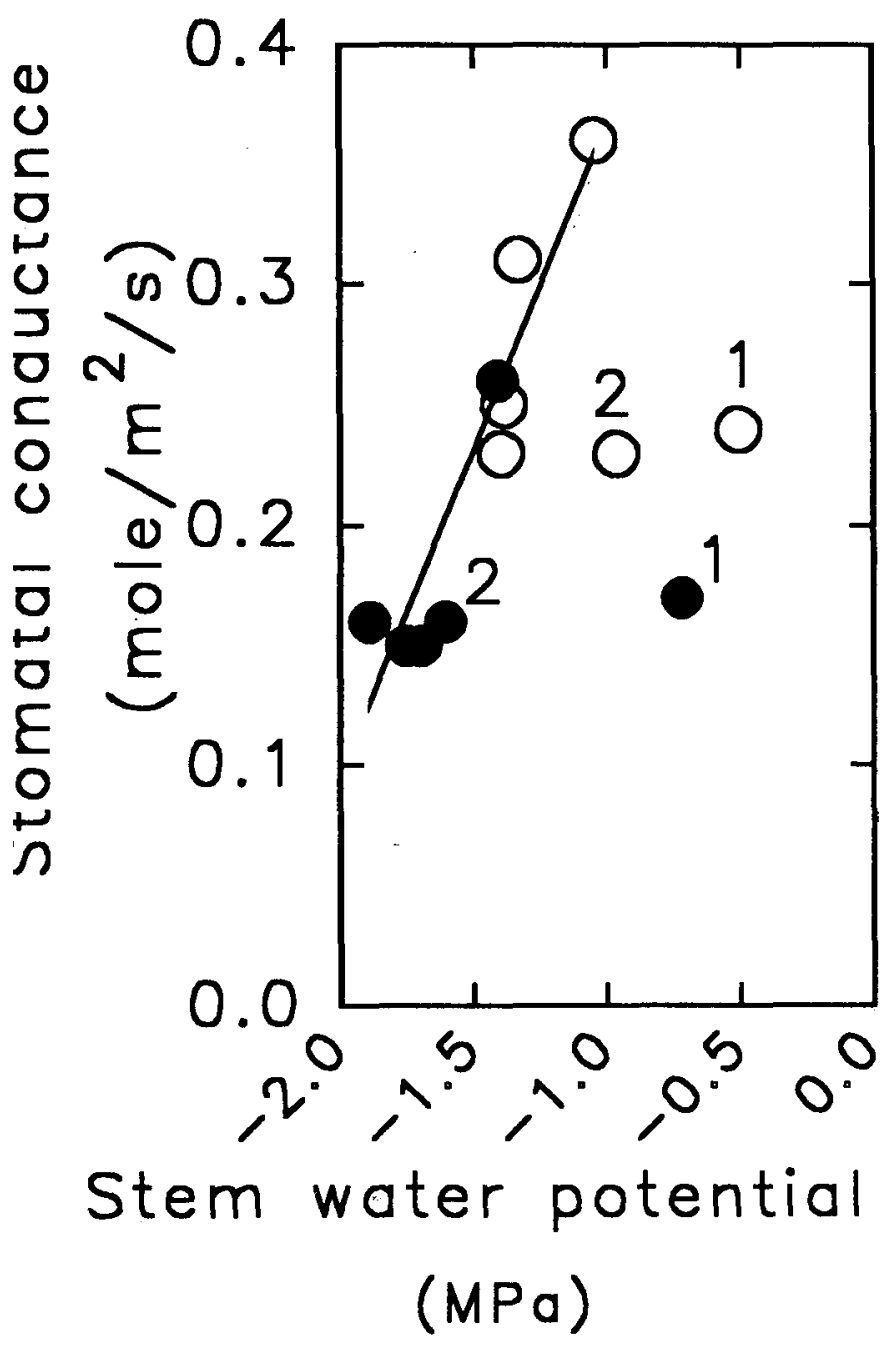

Fig. 6. Stomatal conductance as a function of $\psi_{\text {stem }}$ under low (closed circles) and high (open circles) irrigation treatments. Numbers 1 and 2 denote measurements at 0730 and $1730 \mathrm{HR}$, respectively. The regression line based on data measured from 0930 to $1530 \mathrm{HR}$.

the irrigation treatments. Total yield (both harvests) was similar. It seems that the reduction of crop level by the first harvest stimulated fruit growth and minimized differences in total yield. However, the percentage of small size fruit was higher in L treatment (Table 2). It should be noted that delayed harvest may decrease fruit storage life.

An attempt was made to find a correlation between plant and soil water potentials and yield components (Table 3 ). Stem water potential was highly correlated with the amount of fruit picked in the first harvest $\left(r^{2}=0.72\right)$, the amount of fruit $>65 \mathrm{~mm}$ in the first harvest $\left(r^{2}=0.71\right)$ and in total yield $\left(r^{2}=0.74\right)$. The degree of correlation between water status indicators and yield components was reduced in the following order: $\psi_{\text {stem }}>\psi_{\text {soil-25 }}>\psi_{\text {soil-50 }}>\psi_{\text {lear }}$. Lower correlations were found between all water status indicators and yield components of the second harvest (data not shown).

Stem water potential correlation with other water status indicators reduced in the following order: $\psi_{\text {soil25 } 25}>\psi_{\text {soil.50 }}>\psi_{\text {laaf }}$ (Table 3). This trend was similar to that found when yield components were correlated with water status indicators. The poor correlation of $\psi_{\text {leat }}$ relative to $\psi_{\text {sem }}$ with respect to yield components should be noted. It should be also noted that the location of the tensiometers in the soil is usually determined arbitrarily. Therefore, with similar plant water status, the value of $\psi_{\text {soil }}$ can differ in response to different soil 
Table 1. The effect of irrigation rate during the cell enlargement stage in 'Golden Delicious' apple on yield in the first ( 15 Sept. 1993) and second (15 Oct. 1993) picking dates and on the percentage of marketable fruit from both harvests.

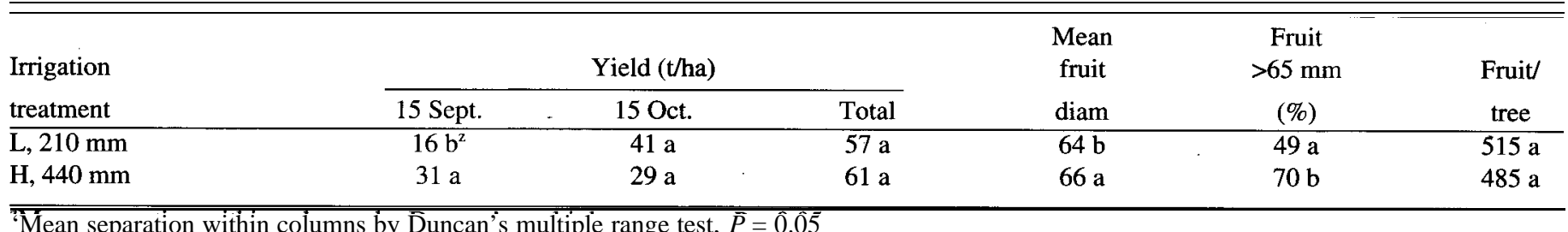

"Mean separation within columns by Duncan's multiple range test, $\bar{P}=\hat{0.05}$

Table 2. The effect of irrigation rate during the cell enlargement stage in 'Golden Delicious' apple on fruit size distribution in the first (15 Sept. 1993) and second (15 Oct. 1993) harvest dates.

\begin{tabular}{|c|c|c|c|c|c|}
\hline \multirow{2}{*}{$\begin{array}{l}\text { Irrigation } \\
\text { treatment }\end{array}$} & \multicolumn{5}{|c|}{ Yield (t/ha) by fruit diam $(\mathrm{mm})$} \\
\hline & $55-60$ & $60-65$ & $65-70$ & $70-75$ & $>75$ \\
\hline \multicolumn{6}{|c|}{ First harvest, 15 Sept. 1993} \\
\hline $\mathrm{L}, 210 \mathrm{~mm}$ & $2 a^{z}$ & $9 \mathrm{~b}$ & $4 b$ & $1 \mathrm{a}$ & --- \\
\hline $\mathrm{H}, 440 \mathrm{~mm}$ & \multicolumn{3}{|c|}{ Second harvest, 15 Oct. 1993} & $5 \mathrm{a}$ & --- \\
\hline $\mathrm{L}, 210 \mathrm{~mm}$ & $10 \mathrm{a}$ & $17 \mathrm{a}$ & $10 \mathrm{a}$ & $3 a$ & $0.3 \mathrm{a}$ \\
\hline $\mathrm{H}, 440 \mathrm{~mm}$ & $5 b$ & $10 \mathrm{~b}$ & $10 \mathrm{a}$ & $3 a$ & $0.8 \mathrm{a}$ \\
\hline
\end{tabular}

'Mean separation within columns, for each harvest, by Duncan's multiple range test, F' $=0.05$.

Table 3. Coefficient of determinations $\left(\mathrm{r}^{2}\right)$ between several yield components and stem $\left(\psi_{\text {stem }}\right)$ and leaf $\left(\psi_{\text {leaf }}\right)$ water potentials and soil water potentials at $25 \mathrm{~cm}\left(\psi_{\text {soil-25 }}\right)$ and $50 \mathrm{~cm}\left(\psi_{\text {soil-50 }}\right)$. Water potentials are average values for days $>200$. Numbers in parentheses are probability level.

\begin{tabular}{|c|c|c|c|c|}
\hline \multirow[b]{2}{*}{ Yield } & \multicolumn{4}{|c|}{ Water potential } \\
\hline & $\psi_{\text {stem }}$ & $\psi_{\text {soil-25 }}$ & $\psi_{\text {soil-50 }}$ & $\psi_{\text {leaf }}$ \\
\hline \multirow[t]{2}{*}{ Total yield first harvest } & 0.72 & 0.49 & 0.31 & 0.14 \\
\hline & $(0.002)$ & $(0.04)$ & $(0.12)$ & $(0.3)$ \\
\hline \multirow[t]{2}{*}{ Total yield >65 mm (\%) } & 0.74 & 0.55 & 0.42 & 0.04 \\
\hline & $(0.01)$ & $(0.03)$ & $(0.06)$ & $(0.6)$ \\
\hline \multirow[t]{2}{*}{ Yield $>65 \mathrm{~mm}$ first harvest $(\mathrm{t} / \mathrm{ha})$} & 0.71 & 0.48 & 0.30 & 0.16 \\
\hline & $(0.003)$ & $(0.04)$ & $(0.13)$ & $(0.25)$ \\
\hline \multirow[t]{2}{*}{$\psi_{\text {stem }}$} & -- & 0.83 & 0.48 & 0.35 \\
\hline & & $(0.001)$ & $(0.04)$ & $(0.08)$ \\
\hline
\end{tabular}

Table 4. Coefficient of determination $\left(r^{2}\right)$ between stomatal conductance and stem water potential $\left(\psi_{\text {stem }}\right)$ and soil water potential at $25 \mathrm{~cm}\left(\psi_{\text {soil2. }}\right)$ at several hours on 4 Aug. 1994. Numbers in parentheses are significance level.

\begin{tabular}{|c|c|c|c|c|c|}
\hline & & \multicolumn{4}{|c|}{ Stomatal conductance } \\
\hline & & $0930 \mathrm{HR}$ & $1130 \mathrm{HR}$ & $1400 \mathrm{HR}$ & $1530 \mathrm{HR}$ \\
\hline \multirow[t]{2}{*}{$\psi_{\text {stem }}$} & & 0.83 & 0.76 & 0.69 & 0.58 \\
\hline & & $(0.001)$ & $(0.001)$ & $(0.01)$ & $(0.02)$ \\
\hline \multirow[t]{2}{*}{$\Psi_{\text {soil- } 25}$} & - & 0.92 & 0.76 & 0.81 & 0.69 \\
\hline & & $(0.001)$ & $(0.02)$ & $(0.001)$ & $(0.01)$ \\
\hline
\end{tabular}

hydraulic properties and root distribution. As hydraulic properties and root distribution are difficult to determine in the field, $\psi_{\text {stem }}$ may have an advantage over use of $\psi_{\text {soil }}$ as a plant water status indicator.

Correlation between $g_{s}$ and both $\psi_{\text {soil }}$ and $\psi_{\text {stem }}$ was high (Table 4). The high correlation between $\mathrm{g}_{\mathrm{s}}$ and $\psi_{\text {soil }}$ can be explained by the control of $g_{s}$ by root signals which are known to be affected by soil moisture (Gowing et al., 1990). The correlation between $\psi_{\text {soil }}$ and $\mathrm{g}_{\mathrm{s}}$ decreased during the day (Table 4). This might relate to the nonsteady flow type of water in the soil toward plant roots. This may reduce $\psi_{\text {soil }}$ uniformity in the root zone throughout the day and reduce the degree of which bulk $\psi_{\text {soil }}$ represents soil moisture availability.

The reduced fruit size in the $\mathrm{L}$ treatment can be explained by lower fruit turgor potential, which is expected to be correlated with $\psi_{\text {stem }}$. Furthermore this may relate to decreased assimilate availability due to the lower $g_{s}$, which was highly correlated with $\psi_{\text {stem }}$. Therefore, $\psi_{\text {stem }}$ is proposed here as a plant water stress indicator concerning fruit size based on physiological considerations and the empiric correlation between higher $\psi_{\text {stem }}$ and larger fruit size.

\section{Literature Cited}

Assaf, R., I. Levin, and B. Bravdo. 1982. Apple fruit growth as a measure of irrigation control. HortScience 17:59-61.

Bollard, E.G. 1970. The physiology and nutrition of developing fruits, p. 387420. In: A.C. Hulme (ed.). The biochemistry of fruits and their products. vol. 1. Academic Press, London.

Boyer, J.S. 1971. Recovery of photosynthesis in sunflower after a period 
of low leaf water potential. Plant Physiol. 47:816-820.

Campbell, G.S. and M.D. Campbell. 1982. Irrigation scheduling using soil moisture measurements: theory and practice. In: D. Hillel (ed.) Advances in irrigation. vol. 1

Ebel. R.C. 1991. Apple tree and fruit response to drought stress. PhD diss. Washington State Univ., Pullman.

Erf, J.A. and J.T.A. Proctor. 1987. Changes in apple leaf water status and vegetative growth as influenced by crop load. J. Amer. Soc. Hort. Sci. 112:617-620.

Forshey, C.G. and B.A. Dominick, Jr. 1965. Irrigation of apples in the Hudson Valley. N.Y. State Agr. Expt. Sta. Bul. 809.

Furr, J.R. and C.A. Taylor. 1939. Growth of lemon fruits in relation to moisture content of the soil. U.S. Dept. Agr. Tech. Bul. 640.

Gamier, E. and A. Berger. 1985. Testing water potential in peach trees as an indicator of water stress. J. Hort. Sci. 60:47-56.

Goel, A. and A. Cohen. 1989. Analysis of fruit growth in grapefruit as affected by irrigation intervals. Scientia Hort. 39:223-233.

Gowing, D. G., W.J. Davies, and H.G. Jones. 1990. A positive root-source signal as an indicator of soil drying in apple, Malus domestics Borkh. J. Expt. Bet. 41:1535-1540.

Jones, H.G. 1992. Plants and Microclimate: A quantitative approach to environmental plant physiology. Cambridge Univ. Press, Cambridge.

Kalmar, D and E. Lahav. 1977. Water requirement of avocado in Israel.
I. Tree and soil parameters. Austral. J. Agr. Res. 28:859-868.

Levin, I., R. Assaf, and B. Bravdo. 1979. Soil moisture and root distribution in an apple orchard irrigated by tickler. Plant Soil 52:31-40.

McCutchan, H. and K.A. Shackel. 1992. Stem-water potential as a sensitive indicator of water stress in prune trees (Prunus domestics L. Cv. French). J. Am. Soc. Hort. Sci. 117:607-611.

Naor, A., B. Bravdo., and Y. Hepner. 1993. Effect of post verason irrigation level on Sauvignon blank yield, juice quality and water relations. S. Afr. J. Enol. Viticult. 14: 19-25.

Naor, A. and R.L. Wample. 1994. Gas exchange and water relations of field-grown Concord (Vitis labrusca) grapevines. Amer. J. Enol. VitiCult. 45:333-337

Olien, W.C. and A.N. Lakso. 1986. Effect of rootstock on apple (Malus domestics) tree water relations. Physiol. Plant. 67:421-430.

Tromp, J. 1984. Diurnal fruit shrinkage in apple as affected by leaf water potential and vapor pressure deficit in the air. Scientia Hort. 22:81-87.

Warrick, A.W. and DR. Nielsen. 1980. Spatial variability of soil physical properties in the field, p.319-344. In: D. Hillel (ed.). Applications of soil physics. Academic Press, New York.

Xiloyanis, C., K. Uriu, and G.C. Martin. 1980. Seasonal and diurnal variations in abscisic acid, water potential, and diffusive resistance in leaves from irrigated and non-irrigated peach trees. J. Amer. Soc. Hort. Sci. 105:412-415. 